JURNAL AL BAYAN: JURNAL JURUSAN PENDIDIKAN BAHASA ARAB

p-ISSN 2086-9282 | e-ISSN 2549-1229

\title{
The Effectiveness of Direct Method in Arabic Language Learning
}

\author{
Umi Chabibatus Zahro ${ }^{1 *}$,Sofri Rizka Amalia ${ }^{2}$, Nur Fadilah Amin ${ }^{3}$ \\ ${ }^{1}$ Elementary School Teacher Study Program, Universitas Peradaban, Indonesia \\ ${ }^{2}$ Mathematics Education Study Program, Universitas Peradaban, Indonesia \\ ${ }^{3}$ Arabic Education Study Program, Universitas Muhammadiyah Makasar, Indonesia
}

Article History:

Received : January 17, 2020

Revised : February 20, 2020

Accepted : March 26, 2020

Published : June 01, 2020

\section{Keywords:}

Arabic; Arithmetic; Student;

Understanding

*Correspondence Address:

umi.chabibah@peradaban.ac.id

\begin{abstract}
Understanding of arithmetic students in Arabic learning is still low. This study aims to determine the effectiveness of the Direct Method in learning Arabic number material in Arabic understanding Arithmetic Students. The approach used is experimental research approach with Posttest-Only Control Design. The population and sample of the study were determined through the Random Sampling technique. Analysis of the data used included normality test, homogeneity test, average similarity test, completeness test, and comparative test. (1) the arithmetic understanding of students taught by the Direct Method in learning 'Adad dan Ma'dud material can exceed the Standard of Minimum Mastery (KKM) of 76,87, (2) the arithmetic understanding of students taught by the Direct Method is 76,87 higher than from the conventional models 65,32. Then it can be concluded that the Direct Method is effective in understanding arithmetic in learning 'Adad dan Ma'dud material. The novelty of this research is that using the Direct Method can facilitate a direct understanding of 'adad and ma'dud. This research contributes in Arabic teaching by using the Direct Method in the material 'Adad and Ma'dud to improve students' arithmetic understanding.
\end{abstract}

\section{Introduction}

'Adad ma'dūd material is a teaching material in the nahwu books. In general, adad ma'dud material in several nahwu books such as jami'uad-durus, qowaidu allughah al-rabiyah is presented globally about the rules of writing only, without any detailed explanations and examples, so the students do not understand the material. ${ }^{1}$ According to Ramadan, a competence Arabic language teacher can identify some of the forms and causes of mistakes made by students in ism 'adad wa al-ma'dud learning. The misunderstanding that usually occurs in adad wa al ma'dud is the concept of adad

${ }^{1}$ Abdul Aziz Khoiri, Tathwiru Darsi Al-'Adadi Wal Ma'dudi Kamaddatin Ta'limiyyatin / Abdul Aziz Khoiri -- (Malang, 2015). 
murakkab. ${ }^{2}$ An educator is expected to look for the problems that occur in students and the causes of the problems.

Previous research studies show that students found difficulties in mastering adad and $m a$ ' $d \bar{u} d$ in Arabic learning. This is because the system of division, concepts and types of adad and $m a$ 'd $\bar{u} d$ in Arabic grammar are different from the concepts used in student's native language. ${ }^{3}$ The results of other studies show that the study found 927 errors relating to al- 'adad and $a l-m a ' d \bar{u} d$. The most errors are in the aspects of $i^{\prime} r a b$, 'adad and ma'dud, followed by errors in the other aspects, and then errors related to writing $m a^{\prime} d u d$, errors in placing the position of 'adad and ma'dud, errors in the equivalent of numbers between 'adad and $m a^{\prime} d u d$ and errors related to writing 'adad. ${ }^{4}$ Hassan mentioned that in the learning process, students also often make mistakes because of misunderstanding the concept of Ism Al-'Adad wa al-Ma' dud and its operations. Even though this topic is considered difficult and confusing, it is a very important language principle in Arabic. ${ }^{5}$

The results of other research observations show that problems in class IV Madrasah Ibtidaiyah Hijraiyah II Palembang are how the students are difficult to understand the material, and there are still many students are noisy in the class, many students cannot focus. ${ }^{6}$ The result of Akyun's observation is the students had problems in learning Arabic, especially in 'Adad Ma'dud (number) material. ${ }^{7}$ This problem is caused because the learning that is taught by the ustadzah (the teacher) does not provide any learning media, it is textbooks oriented only. Hence, the students feel difficult to improve their ability to learn 'adad ma'dud'. ${ }^{9}$ As such, it is necessary to have a method of

${ }^{2}$ Nurul Huda Hassan, Nik Mohd Rahimi Nik Yusof, And Ashraf Ismal, 'Misconceptions On Ism Al-'Adad Wa Al-Ma'dud Among Students Of Arabic Language In Malaysia', Global Journal Of Human Social, 12.9 (2012), 1-7.

${ }^{3}$ Mohamad Hussin And Abdul Hadi Marosadee, 'Pembinaan Modul Pembelajaran Ayat Al-Quran', Issues In Language Studies, 8.1 (2019), 85-103.

${ }^{4}$ Hakim Zaina And Mohd Muslim Abdullah, 'Seminar Pengajaran Dan Pembelajaran Bahasa Arab 2014', In Igarss 2014 (Malaysia: Unisza, 2014), Pp. 1-530 <Https://Doi.Org/10.1007/S13398-014-01737.2>.

${ }^{5}$ Nurul Hudaa Hassan Et.Al., 'Miskonsepsi Terhadap Topik Ism Al-Cadad Wa Al-Macdud Dalam Pembelajaran Bahasa Arab', Journal Of Islamic And Arabic Education, 4.1 (2012), 11-20.

${ }^{6}$ Afni, Pengaruh Penerapan Direct Method (Metode Langsung) Terhadap Hasil Belajar Siswa Kelas Iv Pada Mata Pelajaran Bahasa Arab Di Madrasah Ibtidaiyah Hijriyah Ii Palembang, (Palembang, 2017).

${ }^{7}$ N Azhan And N Shamshirnar, 'International Conference On Islamiyyat Studies 201818 - 19', In 4th International Conference On Islamiyyat Studies 2018, 2018, IV, 185-93.

${ }^{8}$ Qurrata Akyun, Language Games And Its Application In Learning 'Adad Ma'dud (An Experimental Research At Tpa Darul Falah, Gampong Pineung) (Banda Aceh, 2018). 
learning Arabic so that students are able to master the material well and can develop the creativity of students who are more in line with the Arabic language curriculum. ${ }^{10}$

Basic arithmetic operations in Arabic are discussed in number material of Arabic ('Adad and Ma'dud). The number in Arabic is 'adad, the calculated object is called ma'dud. ${ }^{1112}$ One of the Qur'anic studies in the light of language is al-'Adad (count) wa al$M a^{\prime} d u d$ (the calculated objects). ${ }^{13}$ The numerial / number (adady) phrase is a phrase formed by a number element which is the center / core element called 'adad and followed by the attribute element, namely the noun of ma ${ }^{\prime} d u d .{ }^{14}$ There are five kinds of numbers in Arabic, namely 'adad mufrad, 'adad murokkab, 'adad ma'tuf, 'adad 'uqud, and 'adad mudaf. 15

Arithmetic is a branch or a precursor of mathematics that studies the basic operation of numbers. Basic arithmetic operations are addition, subtraction, multiplication and division. The basic arithmetic operations in Indonesian have been studied in elementary school. However, there are still many people who do not understand it. Mathematics as an applied science is widely applied in various fields such as chemistry, physics, biology, economics, astronomy, social sciences, and other fields. Especially in religious, there are a lot of mathematical concepts applied such as inheritance, zakat, determination of 1 Shawwal, the point of Qibla, prayer time and etc. Therefore, a Muslim should have knowledge of arithmetic, number theory, algebra, roots, measurements, geometry, and others. Generally, the mathematical concepts explored are related to algebra, arithmetic, geometry, and others and their use of aspects of religious

${ }^{9}$ Lilis Suaibah, 'Pembelajaran Kaidah Bahasa Arab Di Fakultas Keislaman Universitas Trunojoyo Madura', In Seminar Nasional Dan Call Of Papers Potensi Madura (Madura: Universitas Trunojoyo Madura, 2016), Pp. 138-47.

${ }^{10}$ M.A. Amrulloh, 'Pengembangan Kurikulum Bahasa Arab Pesantren Mu'adalah (Studi Kasus Di Pondok Pesantren Al-Kausar Genteng Banyuwangi)', Jurnal Al Bayan: Jurnal Jurusan Pendidikan Bahasa Arab, 9.2 (2017), 234-48 <https://doi.org/10.24042/albayan.v9i2.2240>.

${ }^{11}$ Iing Misbahuddin, 'Makna Bilangan Angka Dalam Al-Quran', At-Taqaddum, 3.1 (2011), 47-60.

${ }^{12}$ Karim Hafid, 'Relevansi Kaidah Bahasa Arab Dalam Memahami Al-Qur'an', Tafsere, 4.2 (2016), 193-205.

${ }^{13}$ Muh Jabir, ‘Al-'Adad Wa Al-Ma'dud Dalam Alquran', Hunafa, 3.2 (2006), 159-68.

${ }^{14}$ Syindi R Oktaviani And Tolinggi, 'Struktur Frasa Berdasarkan Persamaan Distribusinya Dengan Golongan Kata Dalam Bahasa Arab', Shaut Al-'Arabiyah, 7.2 (2019), 121-31 <Https://Doi.Org/10.24252/Saa.V7i2.10313>.

15 Imam Mul Hakim, “Adad Dan Ma‘Dud Dalam Bahasa Arab Serta Implikasinya Dalam Pembelajaran Bahasa Arab Di Indonesia’, Uin Sunan Kalijaga, 2012. 
rituals. ${ }^{16}$ According to Hudaa, Ism Al-'Adad Wa Al-Ma'dud is a topic that is difficult to be learnt and taught to students, but this topic is an important Arabic principle. ${ }^{17}$

Based on previous research problems, it shows that there is lack of arithmetic understanding especially in 'adad and ma ' $d \bar{u} d$ material. This is consistent with the results of field investigation tests. Based on the results of the initial investigation test shows that there is lack of arithmetic understanding especially in 'adad and $m a$ ' $d \bar{u} d$ material. Here is one of the results of the investigation:

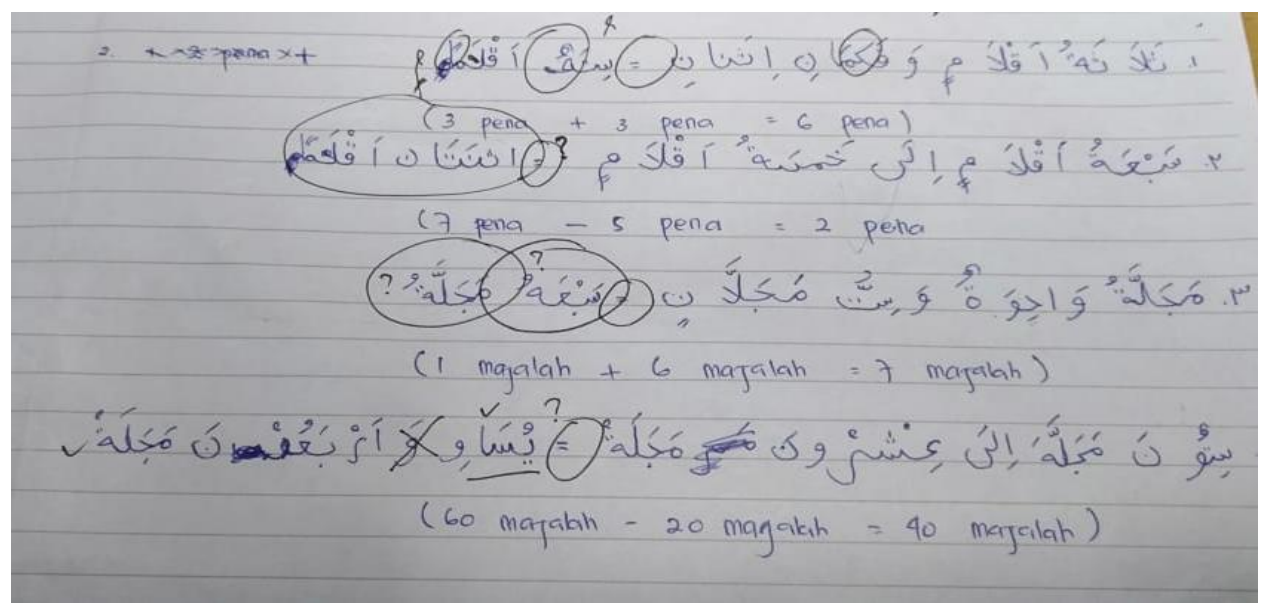

Figure 1. The Result of Investigation

It appears in question number 1 that the operation writing is in Arabic but the calculation is correct. Question number 2 of the addition operation is still incorrect because the Arabic translation is not correct yet. In numbers 3 and 4 both of writing and calculation are not correct yet. Students still don't understand 'adad and ma'dud (basic operations of numbers in Arabic). It happens because students are passive in learning. Students also consider that Arabic is a difficult subject and they are lack of confidence in using Arabic. This is in line with the results of research which mentions an error that occurs is inaccuracy in the application of the 'adad-ma' $d u d^{\prime}{ }^{18}$

One of the efforts that can be done to improve arithmetic understanding is the use of models that are suitable with students' conditions. The various attempts were made to improve the understanding of 'Adad and $M a$ ' $d u d$ material. Here are some studies that raise the problems in Arabic learning. The application of the Direct Method in Arabic

\footnotetext{
${ }^{16}$ Mahdalena, 'Kajian Konsep Bilangan, Bentuk, Dan Koneksi Dalam Al-Quran’, Itqan, 9.2 (2018), $1-15$.

${ }^{17}$ Nurazizah Maarup And Harun Baharudin, 'Pengajaran Dan Pembelajaran Koperatif Abad Ke 21 Ismal- ' Adad Wa Al-Ma' Dud Di Sekolah Menengah', Researchgate, November, 2016, 281-99.

18 Walfajri, 'Pendahuluan Studi Mengenai Kesalahan Bahasa Dalam Kaitannya Dengan Pembelajaran Bahasa Arab Sebagai Bahasa Asing Sangat Fungsional . Melalui Pengkajian Kesalahan Itu , Kesalahan, Klasifikasi Frekuensi Terjadinya Kesalahan , Dan Faktor- Faktor Yang Menyeb', 2018. 
learning in Pesantren (boarding school) al-Falah is suitable with the characteristics and procedures for its application, to support the success of Arabic learning, biughah lughawiyah system is applied. ${ }^{19}$ Other research shows, thariqah mubasyarah or Direct Method in Arabic learning is applied successfully. Nowadays, Gontor has an important role to achieve the success of Arabic learning in this country. ${ }^{20}$ The Direct Method is very relevant to be implemented in Arabic learning especially in Islamic schools and boarding schools, moreover, the Islamic schools and boarding schools want to encourage their students to continue their studies in the Middle East. ${ }^{21}$ The research that was conducted by Afni states the result that the scores of students when the Direct Method is applied are higher than learning without applying Direct Method. ${ }^{22}$

The results of Bagmang's research show that first, the Direct Method in Arabic learning in the modern Islamic boarding schools is already well implemented. It can be proven by the results of a questionnaire that the author has done that $80 \%$ of students can understand the lessons given. Second, the effectiveness of students' learning in Arabic learning through the Direct Method has been effective. ${ }^{23}$ The results found that the application of language games (Al'ab Al-lughawiyah) was effective in increasing the ability of students, because the t-test value was higher than the t-table value $(2.09<9.53>$ 2.86), and it made them easier to learn 'adad dan $m a$ ' $d u d$, based on the observational value of ustadzah's (the teacher) activity is $90 \%$ and the observation value of the students' activity is $90 \%$. So, it shows that the null hypothesis is rejected and the alternative hypothesis is accepted or that the application of language games ( $A l^{\prime} a b A l$ lughawiyah) can improve the ability of students and facilitate them in 'adad and ma'dud learning. ${ }^{24}$

Based on a review of previous research result shows that Direct Method can improve the learning outcomes in learning. The difference between previous research and this research is the application of the Direct Method in Arabic learning related to

\footnotetext{
${ }^{19}$ Muh Arif, 'Metode Langsung (Direct Method) Dalam Pembelajaran Bahasa Arab', Al-Lisan Journal Bahasa \& Pengajarannya, 4.1 (2019), 44-56.

${ }^{20}$ Wisnawati Loeis, 'Metode Langsung Dalam Pembelajaran Bahasa Arab', Turats, 7.2 (2011), 6270.

21 Lina Marlina, 'Efektifitas Metode Langsung Dalam Pengajaran Keterampilan Keterampilan Berbicara Bahasa Arab', Jurnal Al-Tsaqafa, 13.2 (2016), 211-26.

${ }^{22}$ Afni.

${ }^{23}$ Batmang, 'Direct Method Dalam Pembelajaran Bahasa Arab Di Pesantren Modern', Jurnal AlTa'dib, 6.2 (2013), 170-78.

${ }^{24}$ Akyun.
} 
numerics. The novelty of this study is specifically the Direct Method applied to the material 'Adad and Ma'dud. By using the Direct Method, learning Arabic activities on Arabic numerals 'Adad and $M a$ 'dud material is more active and students' arithmetic understanding can be developed. The Direct Method can be applied to all foreign languages, Arabic is no exception. Arabic is one of the languages learned in Indonesia. Arabic is taught during the extracurricular activities or as the main subjects in public schools, islamic boarding schools, madrasah and in the university level. ${ }^{25}$ The application of Direct Methods in learning Arabic is expected to develop one's abilities in Arabic.

Direct Method (al-Tariqatu al-Mubasyarah) emphasizes the practice of continuous conversation between teachers and students using Arabic without using first language whether in explaining the meaning of vocabulary or translating. The method of learning language directly without translation is called the Direct Method or Natural Method or Oral Method or Modern Method or Berlitz Method. When this method is applied, the teacher gives some vocabulary then students memorize it. The memorized words are combined with other words that have also been understood. Then, it is used repeatedly in conversation. ${ }^{26}$ Tariqah Mubasyarah (Direct Method) makes students communicate any time and place. ${ }^{27}$

The existence of the "Direct Method" coincides with a new understanding that determines that all foreign language teaching must be done only in the target language, without translation and emphasis on linking meaning with the language being studied. ${ }^{28}$ The Direct Method was an extension to Gouin and his contemporaries' natural view towards language learning. ${ }^{29}$ Direct Method is suitable to be use in learning foreign languages.

The method is already applied to the Gontor Ponorogo Darussalam Modern Islamic Boarding School which is well-known because of the success in Arabic teaching

\footnotetext{
${ }^{25}$ Tri Yanti Nurul, 'Penerapan Metode Langsung Dalam Pengajaran Percakapan Bahasa Arab Dasar', In Konferansi Nasional Bahasa Arab Iv, 2018, Pp. 140-48 <Https://Doi.Org/10.1017/Cbo9781107415324.004>.

${ }^{27}$ Ratna Sa'idah, 'Arab Yang Bermutu ( Studi Atas Pembelajaran Bahasa Arab Di Lembaga Kursus Bahasa Arab "Al-Farisi ", Realita, 15.1 (2017), 1-16.

${ }^{28}$ Shazli Hasan Khan, 'Arabic Language Teaching In India : Its Place And Scope In The Present Indian Higher Education', Indian Journal Of Research Paripex, 3.4 (2013), 73-77.

29 Haifa Al-Nofaie, 'The Attitudes Of Teachers And Students Towards Using Arabic In Efl Classrooms In Saudi Public Schools- A Case Study', Novitas-Royal (Research On Youth And Language, 4.1 (2010), 64-95.
} 
and learning and their patterns of teaching Arabic with this method. The book used is Durusullughah al-Arabiyyah Volume I. This book teaches about: Arabiyyah vocabulary by directly practicing such as noun (isim), adjectives, verbs (fi'il), numbers ('adad), shape (syakl), color of the object (lawn), vocabulary about the human body (a'dha ul jismi), the direction of the compass (jihah) and etc. ${ }^{30}$ According to Qonita, the application of the Direct Method is one of the models used as a teacher's effort to improve the quality of Arabic learning. ${ }^{31}$ Based on the results of previous studies, it appears that Direct Method is one method that can be used as an alternative to increasing understanding in Arabic learning with a variety of materials.

Direct Method can be applied with the use of language in meaningful situations, for example drama, pictures, tapes, posters, associations etc. It almost eliminates the use of translation in language learning. ${ }^{32}$ The application of Direct Methods in teaching and learning activities in Arabic learning is realized in every individual in the process of language learning, especially in Arabic learning and teaching process, teachers have to use Arabic in their interactions and as an intermediary language in teaching and learning activities. Then, the students will get used to using Arabic. ${ }^{33}$ According to Larsen, the Direct Method has one very basic rule: no translation is allowed. Apparently, the name of Direct Method was from the fact that the meaning must be spoken directly in the target language through the use of demonstrations and visual tools, without any assistance to the students' native language. ${ }^{34}$

Its basic aim is to develop the ability to think in Arabic and not with their native language. ${ }^{35}$ The application of the Direct Method in language learning can help the students to understand the material provided easier, because it is practiced directly without translating. There are three methods that are attached to this method. Even, it is

\footnotetext{
${ }^{30}$ Loeis.

${ }^{31}$ Hilda Qonita, Upaya Guru Dalammeningkatkan Kualitas Pembelajran Bahasa Arab, Universitas Muhammadiyah Surakarta, 2017.

${ }^{32}$ Rami Hamdallah, 'To Use Or Not To Use Arabic In English Language Teaching', An-Najah University Journal Research, 13.1 (1999), 285-95.

${ }^{33}$ Ismail Suardi Wekke, Ernawati, And Hudaya Ujang, 'Aspects Of Arabic Teaching And Learning In Elementary Madrasah On Minority Muslim Indonesia', In The International Conference Arabic Language Education And Literature And Islamic Values Between Expectation And Realization, 2016, III, 1-11 <Https://Doi.Org/Https://Doi.Org/10.3929/Ethz-B-000238666>.

${ }^{34}$ Freeman Diane Larsen And Marti Anderson, Technique \& Principles In Language Teaching, Ed. By 3 (Cina: Oxford, 2011).

${ }^{35}$ Dihin Muriyatmoko, Faisal Reza Pradhana, And Zaenury Adhiim Musyafa', 'Durus Al-Lughah Gontory: Media Pembelajaran Bahasa Arab Untuk Pemula Menggunakan Metode Langsung', Jurnal Teknologi Informasi Dan Ilmu Komputer, 6.1 (2019), 77 <Https://Doi.Org/10.25126/Jtiik.2019611259>.
} 
the important part in Direct Method that will be explained as follows: (1) psychological method that accentuates their learning process on observing mental development and mind association, (2) phonetic methods, it is writing material in phonetic, not spelling that is commonly used. In practice, this method begins the learning process with listening exercises, and (3) the natural method which is a continuation of the phonetic method. This method equates the way of learning a foreign language with a native language that is usually based on everyday behaviour and habits that occur naturally. ${ }^{36}$

\section{Method}

This research was located at the Faculty of Teacher Training and Education (FKIP) University of Peradaban. This type of research is quantitative experimental research. The approach of this research is experimental research. The experimental design used in this study was 'Post-test-Only Control Design'. The population of this research was students of mathematics education, English language education (PBI), Elementary School Teacher Education (PGSD). The sample of this study was PGSD 2 students as the experimental class and PBI as the control class. In this study, Sampling used Simple Random Sampling. The data collection techniques of this study were interviews, observation, documentation and tests. Calculation of the validity of the test questions is done by using the product moment correlation technique. ${ }^{37}$ From the results of the validity test showed that the five questions were considered to be valid. The calculation of the reliability of the test was done by using Cronbach's Alpha. ${ }^{38}$ Comparing and difficulty level using the type of problem description. ${ }^{39}$ The prerequisite test is carried out first, namely the normality test, the homogeneity test, and the average similarity test. Then a statistical analysis is performed, namely average similarity test, completeness test, and comparative test.

\section{Result and Discussion}

The learning process carried out in this study is learning and teaching by using Direct Method in 'Adad and Ma'dud material. There are steps in Arabic learning on

\footnotetext{
${ }^{36}$ Asriyah, 'Metode Langsung Dalam Pengajaran Bahasa Arab’, Jurnal Adabiyah, 11.1 (2011), 84-
} 92.

${ }^{37}$ Arikunto, S. Prosedur Penelitian Suatu Pendekatan Praktek. Jakarta: Rineka Cipta, 2012.

${ }^{38}$ Febrinawati Yusup, 'Uji Validitas Dan Reliabilitas Instrumen Penelitian Kuantitatif', Jurnal Tarbiyah : Jurnal Ilmiah Kependidikan, 7.1 (2018), 17-23 <https://doi.org/10.18592/tarbiyah.v7i1.2100〉. 
'Adad and Ma'dud material that are stated as follows: all learning activities use foreign languages (Arabic), in explaining the meaning of the word, efforts are made to the techniques, including: (a) Showing concrete objects that are the meanings of the word in question, such as one pen, two books and so on to explain the meaning of it. (b) Demonstrating by actions to explain the meaning of the sentence, such as: 'isytaroitu kitaabaini itsnaini' that means 'I have bought two books'. (c) Playing a role (drama) by using Arabic related to 'Adad and Ma'dud. (d) Mentioning the opposite word. (e) Calling synonyms. (f) Associating, such as saying a word that reminds the mind of mentioning another word. (g) Mentioning the main sentence and its musytaq. (h) Explaining the meaning of words or sentences. (i) Translating into the language of instruction.

The application of the Direct Method in Arabic learning helps the students to understand 'Adad and $M a^{\prime} d u d$ material easier. This is because students directly speak out the Arabic vocabulary, understand the meaning of words, and practice directly when performing roles in drama related to 'Adad and $M a$ 'dud. After learning is carried out, students are given a test to determine the understanding of student in arithmetic. The results of the tests carried out the prerequisite test and completeness test.

\section{Prerequisite Analysis}

The final data normality test of the sample class is done to know that the sample data can represent the entire population and as a prerequisite for further data testing. The results of normality test calculations can be seen in Table 1 .

Table 1. The Result Of Data Normality Test

\begin{tabular}{lccc|c}
\hline \multirow{2}{*}{ Kelas } & \multicolumn{3}{c}{ Kolmogorov-Smirnova } \\
\cline { 2 - 5 } & Statistic & Df & Sig. \\
\hline \multirow{2}{*}{ Post test score } & Direct Method &, 163 & 23 &, $118^{*}$ \\
& Expository &, 172 & 19 & 142 \\
\hline
\end{tabular}

Based on Table 1, it is obtained sig in experimental class $=0.118$ and sig in control class $=0.142$, whereas sig value of the two classes is more than 0.05 , then $\mathrm{H}_{0}$ is accepted. So, the final data of both classes comes from populations that are normally distributed. Homogeneity test of initial sample class data is done to find out that both groups have the same or homogeneous variance. Homogeneity test results can be seen in Table 2.

\footnotetext{
${ }^{39}$ Yusup.

157 | Jurnal Al Bayan: Jurnal Jurusan Pendidikan Bahasa Arab, 12 (1): 149-164 (2020)
} 
Table 2. The Result of Homogeneity Test

\begin{tabular}{|c|c|c|c|}
\hline & & \multicolumn{2}{|c|}{$\begin{array}{c}\text { Levene's Test for Equality o } \\
\text { Variances }\end{array}$} \\
\hline & & $\mathrm{F}$ & Sig. \\
\hline Test score & $\begin{array}{c}\text { Equal variances assumed } \\
\text { Equal variances not assumed }\end{array}$ & ,476 & ,001 \\
\hline
\end{tabular}

It can be seen in Table 2. It is found that the sig value of the experimental class and control class $=0.001$ is less than sig 0.05 , then $\mathrm{H}_{0}$ is accepted. It means that the two classes have different variances after being treated.

\section{Completeness Test}

The results of the completeness test can be seen in Table 3 namely the column output of equal variances not assumed as follows:

Table 3. The Result of Completeness Test

\begin{tabular}{cccc}
\hline & \multicolumn{3}{c}{ Test Value $=70$} \\
\cline { 2 - 4 } & $T$ & Df & Sig (2-tailed) \\
\hline Direct Method class & 7,819 & 22 &, 000 \\
\hline
\end{tabular}

In Table 3. Obtained $\mathrm{t}_{\text {count }}=7,819$ with $\alpha=5 \%$ and $d k=22-1=21$ obtained $t_{\text {table }}$ $=1,717$. Because $t_{\text {count }} \geq t_{\text {table }}=7,819 \geq 1,717$, then, $H_{0}$ is rejected. So, the average understanding of arithmetic with the Direct Method in Arabic learning on numbers material has reached 70 .

The comparative test results can be seen in Table 4 which shows that Equal not variances assumed line obtained $\mathrm{t}=4.665$ with $d k=(23+19-2)=40$ and obtained $t_{\text {table }}=1.684$, then $t_{\text {count }}>t_{\text {table }}=4,665>1,684$, so it was rejected.

Tabel 4. The Result of Comparative Test

\begin{tabular}{ccccrrr}
\hline & \multicolumn{2}{c}{$\begin{array}{c}\text { Levene's Test for } \\
\text { Equality of Variances }\end{array}$} & \multicolumn{3}{c}{ t-test for Equality of Means } \\
\cline { 2 - 6 } & $\mathrm{F}$ & Sig & T & Df & \multicolumn{2}{c}{ Sig (2-Tailed) } \\
\hline $\begin{array}{c}\text { Nilai Posttest Equal variances assumed } \\
\begin{array}{c}\text { Equal variances not } \\
\text { assumed }\end{array}\end{array}$ & 13,430 &, 001 & 40 & 000 \\
\hline
\end{tabular}

So it can be said that, the average test results of students 'arithmetic understanding that are taught by using the Direct Method is better than the average results of students' arithmetic understanding tests that are taught using conventional models. Based on the research results it can be concluded that the Direct Method is effective in understanding arithmetic in learning 'Adad and Ma'dud material. This is in line with the results of 
research showing that teaching strategies that combine various approaches, methods and techniques, together with creative analogies and adaptation of textbook content according to the student environment will open the way to the best and most effective teaching. ${ }^{40}$ The results of other studies show that Grammar Translation Method and Direct Method have obtained the highest percentage (69\%), which agrees that both methods have often been applied in practical periods. Besides that, it seems that all of these students are familiar with teaching methods used in teaching and learning process based on a high percentage $(95.2 \%)$ of their perception of all of these methods. ${ }^{41}$ The Direct Method has an influence in teaching and learning in Islamic Middle School Class VII. ${ }^{42}$

Other research shows that the characteristics of Direct Method can be used to practice their ability of verbal communication quickly through question and answer in varied patterns of interaction, so that teachers and students play an active role in the communication created. Thus, basic Arabic conversation will be easier to master and apply in communication. The Direct Method is applied as a teaching strategy allowing students to speak Arabic without feeling embarrassed and afraid to make mistake. ${ }^{43}$ Other results show that learning methods based on the communicative approach are methods that place more emphasis on listening and speaking skills. The learning objectives that is achieved through a variety of methods is learners are able to communicate with the target language learned whenever and wherever which is suitable with the nature of language learning. ${ }^{44}$

Other studies mention that learning outcomes of students in Arabic learning by using Direct Method is efficient. ${ }^{45}$ Suswanto's research results show that learning Arabic with Direct Method in Aliyah Al-Ishlah Madrasah has a positive impact. ${ }^{46}$ The results of

${ }^{40}$ Hassan, Yusof, And Ismal.

${ }^{41}$ Suo Yan Mei And Others, 'The Arabic Teacher's Training And The Effect Of Their Work Success: A Case Study Of Sultan Idris Education University (Upsi)', European Journal Of Language And Literature, 5.1 (2016), 14 <Https://Doi.Org/10.26417/Ejls.V5i1.P14-21>.

42 Dwi Valentina Puspita, 'Pengaruh Penggunaan Metode Langsung Terhadap Pembelajaran Keterampilan Berbicara Untuk Siswa Kelas Vii Di Madrasah Tsanawiyah Negeri 1 Pacitan Tahun Ajaran 2018/2019', 2019.

${ }^{43}$ M. Adnan And Others, 'Teachers' Attitudes Towards The Use Of First Language In Arabic Classroom', Researchers World - Journal Of Arts, Science \& Commerce, 5.2 (2014), 20-28.

44 M Husni Arsyad, 'Metode-Metode Pembelajaran Bahasa Arab Berdasarkan Pendekatan Komunikatif Untuk Meningkatkan Kecakapan Berbahasa', Shaut Al-'Arabiyah, 17.1 (2019), 13-30 <https://doi.org/10.24252/saa.v1i1.8269>.

${ }^{45}$ Nova Yanti, Nurul Afrani, And Nova Yanti, 'Efektivitas Pembelajaran Bahasa Arab Dengan', 10.2 (2018), 231-43.

${ }^{46}$ Kamala Suwanto, Penerapan Metode Langsung Dalam Pembelajaran Bahasa Arab Pada Siswi Kelas Xi Sd, 2019. 
other studies show that although the methods of teaching Arabic are double, there is no unique way of teaching, each method has its own advantages and disadvantages. But based on the results, most students and teachers find that the Direct Method is highly recommended to be applied in Arabic class. ${ }^{47}$ Bakri stated that Direct Method is significant in Arabic teaching, because through this method students can directly practice their skills without using their mother tongue (first language). ${ }^{48}$ Even though, it seems difficult for students to imitate at the beginning, but this method is interesting for students. ${ }^{49}$

Thus, the similarity of this study based on the results and previous studies is the application of the Direct Method can improve the students' abilities in Arabic learning. While the novelty of this research is that by using the Direct Method can facilitate a direct understanding of 'adad and ma'dud. Students can use and pronounce various kinds of numbers in Arabic directly. It helps the students to understand easier and make the process of Arabic learning more meaningful. The use of Direct Methods contributes to the teaching of Arabic in the material 'Adad and Ma'dud to improve students' arithmetic understanding.

\section{Conclusion}

Based on the description above, the conclusions of this study are (1) arithmetic understanding of students taught by the Direct Method in learning Arabic material 'Adad and Ma'dud can exceed the Standard of Minimum Mastery (KKM) that is 76.87, (2) the average understanding of arithmetic students taught by the Direct Method is 76.87 which is higher than the conventional model that is 65.32 . Then it can be concluded that the Direct Method is effective in understanding arithmetic in Arabic learning on 'Adad and $M a^{\prime} d u d$ material. The use of Direct Methods contributes to the teaching of Arabic in the material 'Adad and Ma'dud to improve students' arithmetic understanding. The novelty of this research is that using the Direct Method can facilitate a direct understanding of 'adad

\footnotetext{
${ }^{47}$ Ma Xuan And Suo Yan Mei, 'Direct Method For Teaching Arabic Language In Tongxin Arabic College Of Ningxia In China', European Journal Of Language And Literature, 4.3 (2018), 52 <Https://Doi.Org/10.26417/Ejls.V4i3.P52-59>.

${ }^{48}$ Roifatul Azizah And Kharidatun Nafisah, 'Penerapan Metode Musyasarah Dalam Pembelajaran Al-'Arabiyyah Lil Athfal', In Inovasi Media Pembelajaran Bahasa, Sastra, Dan Budaya Arab, 2019, Pp. $129-53$.

49 Ali Bakri Bakri, 'Metode Langsung (Direct Method) Dalam Pembelajaran Bahasa Arab', AlMaraji', 1.1 (2017), 1-102 <https://doi.org/10.30603/al.v4i1.605>.
} 
and $m a^{\prime} d u d$. Students can use and pronounce Arabic directly various kinds of numbers. The use of Direct Methods contributes to the Arabic teaching on 'Adad and Ma'dud material to improve students' arithmetic understanding. This study examines the application of the Direct Method can be seen from students' arithmetic understanding. Many other variables can be improved by applying the Direct Method. Variables that can be improved in other studies are cognitive, psychomotor and affective aspects such as mathematical communication skills, Arabic speaking skills, numeracy skills, motivation and others.

\section{Acknowledgment}

Thanks to the University of Peradaban for providing the opportunity to researchers and all of those who helped to carry out this research.

\section{References}

Adnan, M., S. Mohamad, M. Yusoff, And Z. Ghazali, 'Teachers`Attitudes Towards The Use Of First Language In Arabic Classroom', Researchers World - Journal Of Arts, Science \& Commerce, 5.2 (2014), 20-28

Afni, Pengaruh Penerapan Direct Method (Metode Langsung) Terhadap Hasil Belajar Siswa Kelas Iv Pada Mata Pelajaran Bahasa Arab Di Madrasah Ibtidaiyah Hijriyah Ii Palembang, Pengaruh Penerapan Direct Method (Metode Langsung) Terhadap Hasil Belajar Siswa Kelas Iv Pada Mata Pelajaran Bahasa Arab Di Madrasah Ibtidaiyah Hijriyah Ii Palembang (Palembang, 2017)

Akyun, Qurrata, Language Games And Its Application In Learning 'Adad Ma'dud (An Experimental Research At Tpa Darul Falah, Gampong Pineung) (Banda Aceh, 2018)

Al-Nofaie, Haifa, 'The Attitudes Of Teachers And Students Towards Using Arabic In Efl Classrooms In Saudi Public Schools- A Case Study', Novitas-Royal (Research On Youth And Language, 4.1 (2010), 64-95

Amrulloh, M.A., 'Pengembangan Kurikulum Bahasa Arab Pesantren Mu'adalah (Studi Kasus Di Pondok Pesantren Al-Kausar Genteng Banyuwangi)', Jurnal Al Bayan: Jurnal Jurusan Pendidikan Bahasa Arab, 9.2 (2017), 234-48 <Https://Doi.Org/10.24042/Albayan.V9i2.2240>

Arif, Muh, 'Metode Langsung (Direct Method) Dalam Pembelajaran Bahasa Arab', AlLisan Journal Bahasa \& Pengajarannya, 4.1 (2019), 44-56

Arsyad, M Husni, 'Metode-Metode Pembelajaran Bahasa Arab Berdasarkan Pendekatan Komunikatif Untuk Meningkatkan Kecakapan Berbahasa', Shaut Al-'Arabiyah, 17.1 (2019), 13-30 <Https://Doi.Org/10.24252/Saa.V1i1.8269> 
Asriyah, 'Metode Langsung Dalam Pengajaran Bahasa Arab', Jurnal Adabiyah, 11.1 (2011), 84-92

Azhan, N, And N Shamshirnar, 'International Conference On Islamiyyat Studies 201818 - 19', In 4th International Conference On Islamiyyat Studies 2018, 2018, IV, 185 93

Azizah, Roifatul, And Kharidatun Nafisah, 'Penerapan Metode Musyasarah Dalam Pembelajaran Al-'Arabiyyah Lil Athfal', In Inovasi Media Pembelajaran Bahasa, Sastra, Dan Budaya Arab, 2019, Pp. 129-53

Bakri, Ali Bakri, 'Metode Langsung (Direct Method) Dalam Pembelajaran Bahasa Arab', Al-Maraji', 1.1 (2017), 1-102 <Https://Doi.Org/10.30603/Al.V4i1.605>

Batmang, 'Direct Method Dalam Pembelajaran Bahasa Arab Di Pesantren Modern', Jurnal Al-Ta'dib, 6.2 (2013), 170-78

Hafid, Karim, 'Relevansi Kaidah Bahasa Arab Dalam Memahami Al-Qur'an', Tafsere, 4.2 (2016), 193-205

Hakim, Imam Mul, “Adad Dan Ma‘Dud Dalam Bahasa Arab Serta Implikasinya Dalam Pembelajaran Bahasa Arab Di Indonesia', Uin Sunan Kalijaga, 2012

Hamdallah, Rami, 'To Use Or Not To Use Arabic In English Language Teaching', AnNajah University Journal Research, 13.1 (1999), 285-95

Hassan, Nurul Huda, Nik Mohd Rahimi Nik Yusof, And Ashraf Ismal, 'Misconceptions On Ism Al-'Adad Wa Al-Ma'dud Among Students Of Arabic Language In Malaysia’, Global Journal Of Human Social, 12.9 (2012), 1-7

Hussin, Mohamad, And Abdul Hadi Marosadee, 'Pembinaan Modul Pembelajaran Ayat Al-Quran', Issues In Language Studies, 8.1 (2019), 85-103

Jabir, Muh, 'Al-’Adad Wa Al-Ma'dud Dalam Alquran', Hunafa, 3.2 (2006), 159-68

Khan, Shazli Hasan, 'Arabic Language Teaching In India: Its Place And Scope In The Present Indian Higher Education', Indian Journal Of Research Paripex, 3.4 (2013), 73-77

Khoiri, Abdul Aziz, Tathwiru Darsi Al-'Adadi Wal Ma'dudi Kamaddatin Ta'limiyyatin / Abdul Aziz Khoiri -- (Malang, 2015)

Larsen, Freeman Diane, And Marti Anderson, Technique \& Principles In Language Teaching, Ed. By 3 (Cina: Oxford, 2011)

Loeis, Wisnawati, 'Metode Langsung Dalam Pembelajaran Bahasa Arab', Turats, 7.2 (2011), 62-70

Maarup, Nurazizah, And Harun Baharudin, 'Pengajaran Dan Pembelajaran Koperatif Abad Ke 21 Ismal- ' Adad Wa Al-Ma' Dud Di Sekolah Menengah', Researchgate, November, 2016, 281-99 
Mahdalena, 'Kajian Konsep Bilangan, Bentuk, Dan Koneksi Dalam Al-Quran', Itqan, 9.2 (2018), 1-15

Marlina, Lina, 'Efektifitas Metode Langsung Dalam Pengajaran Keterampilan Keterampilan Berbicara Bahasa Arab', Jurnal Al-Tsaqafa, 13.2 (2016), 211-26

Mei, Suo Yan, Zarima Zakaria, Zalika Adam, And Suo Yan Ju, 'The Arabic Teacher's Training And The Effect Of Their Work Success: A Case Study Of Sultan Idris Education University (Upsi)', European Journal Of Language And Literature, 5.1 (2016), 14 <Https://Doi.Org/10.26417/Ejls.V5i1.P14-21>

Misbahuddin, Iing, 'Makna Bilangan Angka Dalam Al-Quran', At-Taqaddum, 3.1 (2011), 47-60

Muriyatmoko, Dihin, Faisal Reza Pradhana, And Zaenury Adhiim Musyafa', 'Durus A1Lughah Gontory: Media Pembelajaran Bahasa Arab Untuk Pemula Menggunakan Metode Langsung', Jurnal Teknologi Informasi Dan Ilmu Komputer, 6.1 (2019), $77<$ Https://Doi.Org/10.25126/Jtiik.2019611259>

Nurul Hudaa Hassan Et.Al., 'Miskonsepsi Terhadap Topik Ism Al-Cadad Wa AlMacdud Dalam Pembelajaran Bahasa Arab', Journal Of Islamic And Arabic Education, 4.1 (2012), 11-20

Nurul, Tri Yanti, 'Penerapan Metode Langsung Dalam Pengajaran Percakapan Bahasa Arab Dasar', In Konferansi Nasional Bahasa Arab Iv, 2018, Pp. 140-48 <Https://Doi.Org/10.1017/Cbo9781107415324.004>

Oktaviani, Syindi R, And Tolinggi, 'Struktur Frasa Berdasarkan Persamaan Distribusinya Dengan Golongan Kata Dalam Bahasa Arab', Shaut Al-'Arabiyah, 7.2 (2019), 121-31 <Https://Doi.Org/10.24252/Saa.V7i2.10313>

Puspita, Dwi Valentina, 'Pengaruh Penggunaan Metode Langsung Terhadap Pembelajaran Keterampilan Berbicara Untuk Siswa Kelas Vii Di Madrasah Tsanawiyah Negeri 1 Pacitan Tahun Ajaran 2018/2019', 2019

Qonita, Hilda, Upaya Guru Dalammeningkatkan Kualitas Pembelajran Bahasa Arab, Universitas Muhammadiyah Surakarta, 2017

Sa'idah, Ratna, 'Arab Yang Bermutu ( Studi Atas Pembelajaran Bahasa Arab Di Lembaga Kursus Bahasa Arab “ Al-Farisi ”, Realita, 15.1 (2017), 1-16

Suaibah, Lilis, 'Pembelajaran Kaidah Bahasa Arab Di Fakultas Keislaman Universitas Trunojoyo Madura', In Seminar Nasional Dan Call Of Papers Potensi Madura (Madura: Universitas Trunojoyo Madura, 2016), Pp. 138-47

Suwanto, Kamala, Penerapan Metode Langsung Dalam Pembelajaran Bahasa Arab Pada Siswi Kelas Xi Sd, 2019

Walfajri, 'Pendahuluan Studi Mengenai Kesalahan Bahasa Dalam Kaitannya Dengan Pembelajaran Bahasa Arab Sebagai Bahasa Asing Sangat Fungsional . Melalui Pengkajian Kesalahan Itu , Kesalahan, Klasifikasi Frekuensi Terjadinya Kesalahan 
, Dan Faktor- Faktor Yang Menyeb', 2018

Wekke, Ismail Suardi, Ernawati, And Hudaya Ujang, 'Aspects Of Arabic Teaching And Learning In Elementary Madrasah On Minority Muslim Indonesia', In The International Conference Arabic Language Education And Literature And Islamic Values Between Expectation And Realization, 2016, III, 1-11 <Https://Doi.Org/Https://Doi.Org/10.3929/Ethz-B-000238666>

Xuan, Ma, And Suo Yan Mei, 'Direct Method For Teaching Arabic Language In Tongxin Arabic College Of Ningxia In China', European Journal Of Language And Literature, 4.3 (2018), 52 <Https://Doi.Org/10.26417/Ejls.V4i3.P52-59>

Yanti, Nova, Nurul Afrani, And Nova Yanti, 'Efektivitas Pembelajaran Bahasa Arab Dengan', 10.2 (2018), 231-43

Yusup, Febrinawati, 'Uji Validitas Dan Reliabilitas Instrumen Penelitian Kuantitatif', Jurnal Tarbiyah: Jurnal Ilmiah Kependidikan, 7.1 (2018), 17-23 <Https://Doi.Org/10.18592/Tarbiyah.V7i1.2100>

Zaina, Hakim, And Mohd Muslim Abdullah, 'Seminar Pengajaran Dan Pembelajaran Bahasa Arab 2014', In Igarss 2014 (Malaysia: Unisza, 2014), Pp. 1-530 <Https://Doi.Org/10.1007/S13398-014-0173-7.2> 